\title{
Correction to: Pre-ovipositional maternal care alleviates food stress of offspring in the flower beetle Dicronocephalus wallichii
}

\author{
Wataru Kojima ${ }^{1,2}\left(\right.$ C) $\cdot$ Chung-Ping $\operatorname{Lin}^{2}$ (1)
}

Published online: 31 December 2018

(c) The Author(s) 2018

\section{Correction to: Journal of Ethology (2018) 36:135-141 https://doi.org/10.1007/s10164-018-0544-1}

The article Pre-ovipositional maternal care alleviates food stress of offspring in the flower beetle Dicronocephalus wallichii, written by Wataru Kojima and Chung-Ping Lin was originally published electronically on the publisher's internet portal (currently SpringerLink) on 13 March, 2018 without open access. With the author(s)' decision to opt for Open Choice the copyright of the article changed on 31 December, 2018 to (C) The Author(s) 2018 and the article is forthwith distributed under the terms of the Creative Commons Attribution 4.0 International License (http://creativecommons .org/licenses/by/4.0/), which permits use, duplication, adaptation, distribution and reproduction in any medium or format, as long as you give appropriate credit to the original author(s) and the source, provide a link to the Creative Commons license and indicate if changes were made.

The original article has been corrected.

Open Access This article is distributed under the terms of the Creative Commons Attribution 4.0 International License (http://creativeco mmons.org/licenses/by/4.0/), which permits unrestricted use, distribution, and reproduction in any medium, provided you give appropriate credit to the original author(s) and the source, provide a link to the Creative Commons license, and indicate if changes were made.
The original article can be found online at https://doi.org/10.1007/ s10164-018-0544-1.

\section{Wataru Kojima}

koj.wataru@gmail.com

1 Graduate School of Sciences and Technology for Innovation, Yamaguchi University, 1677-1 Yoshida, Yamaguchi City, Yamaguchi 7538511, Japan

2 \footnotetext{
University, No. 88, Section 4, Tingzhou Road, Taipei 11677, Taiwan
} 